\title{
Establishing a Baseline Measure of School Wellness-Related Policies Implemented in a Nationally Representative Sample of School Districts
}

\begin{abstract}
The Child Nutrition and WIC Reauthorization Act of 2004 required school districts to establish a local school wellness policy by the first day of the 2006-2007 school year. To provide a baseline measure of the extent to which wellness-related policies were implemented in school districts nationwide in 2006, this study analyzed data from the 2006 School Health Policies and Programs Study (SHPPS). SHPPS used a crosssectional design to measure policies and practices among a nationally representative sample of 538 public school districts. The authors applied a standardized wellness policy coding system to the data by matching each element to relevant questions from SHPPS and calculated the percentage of school districts meeting each element in the coding system. Statistical analyses included calculation of $95 \%$ confidence intervals for percentages and mean number of elements met in each area. In 2006, none of the districts met all elements included in the coding system for local wellness policies. In addition, the percentage of districts meeting each element varied widely. On average, districts met the greatest number of elements in the area of nutrition education, and the least number of elements in the area of physical activity. By applying a coding system for district policies to an existing dataset, this study used a novel approach to determine areas of strength and weakness in the implementation of local school wellness-related policies in 2006.
\end{abstract}


The Child Nutrition and WIC Reauthorization Act of 2004 (PL 108-265, Section 204) required school districts participating in the National School Lunch Program or other child nutrition programs to establish a local school wellness policy by the first day of the 2006-2007 school year (1). According to this law, policies were required to include the following elements: goals for nutrition education, physical activity, and other schoolbased activities designed to promote student wellness; nutrition guidelines for all foods available on each school campus during the school day; an assurance that guidelines for reimbursable school meals shall not be less restrictive than federal school meal standards; a plan for measuring implementation of the policy; and the involvement of parents, students, the school food authority, the school board, school administrators, and the public in the development of the policy.

Several studies have provided assessments of the quality of local school wellness policies that were written following this mandate (2-9). In an early study, Metos and Nanney (2) collected written policies from 30 school districts in Utah. At that time, no standardized scoring tool existed; however, the authors assessed the extent to which the policies complied with federal and state guidelines and scored policies according to the strength of the language. In another study, researchers from Action for Healthy Kids collected policies from a convenience sample of 256 districts of varying sizes from all states except Hawaii (3). They compared the policies to the federal legislation and to the Action for Healthy Kids' Wellness Policy Fundamentals, a tool created to guide districts on the development and evaluation of policies (10). While this was a systematic analysis, the policy assessment was qualitative rather than quantitative in nature. 
To more rigorously evaluate local school wellness policies, Schwartz and colleagues (11) developed a quantitative coding system that can be used to score these policies on comprehensiveness and strength in seven goal areas: nutrition education, standards for USDA child nutrition programs and meals, standards for competitive and other foods and beverages, physical education, physical activity, communication and promotion, and evaluation. Psychometric testing revealed that this system provides a reliable method for analyzing and comparing wellness policies (11). This coding system has since been shortened to meet the needs of educators and policymakers; this new Wellness School Assessment Tool, or WellSAT, is available online (12).

Building on the work of Schwartz and colleagues, Chriqui and colleagues conducted the largest nationwide evaluation of wellness policies to date (6). As in prior studies of wellness policies, they found that while most districts adopted a wellness policy, the policies generally were underdeveloped and fragmented. One of the unique contributions of the study by Chriqui and colleagues was the adaptation of the coding scheme developed by Schwartz et al. (11) to code for grade-level distinctions. This proved to be particularly important for the competitive food and beverage coding categories.

In the Schwartz and Chriqui studies, the coding system used was designed to be applied to the local school board's written policies and procedures and to any associated implementation rules or regulations developed by district superintendents $(6,11)$. These documents usually can be obtained from school district offices or web sites. Such policies vary widely in the level of detail provided (6) and do not necessarily reflect actual district-level implementation. To better understand and document the range of wellness- 
related policies implemented in school districts nationwide before the local wellness policy requirements took effect, the present study uses the original Schwartz et al. (11) version of the coding system to provide a framework to organize existing data on districtlevel policies addressing a range of school health-related topics. The authors used the original coding system rather than the enhanced version because the existing data did not provide information on how policies might vary by grade level.

The data used for this study is the nationally representative sample of school districts surveyed as part of the 2006 School Health Policies and Programs Study (SHPPS). Conducted every six years by the Centers for Disease Control and Prevention (CDC), SHPPS assesses all areas of school health, including many of the elements contained in school wellness policies, such as the school food environment. Because the majority of the SHPPS 2006 data collection occurred before the local wellness policy requirement took effect, these data provide a baseline measure of the implementation of district-level policies pertaining to school wellness. The purpose of this study, therefore, was to use existing data to determine the percentage of school districts in 2006 meeting the elements contained in an established wellness policy coding system. The authors hypothesized that districts were unlikely to have met many of these elements.

\section{METHODS}

\section{Participants and Instruments}

SHPPS 2006 used a cross-sectional study design and collected data at the state, district, school, and classroom levels. Because local wellness policies are intended to be implemented at the district level, the current analysis used the SHPPS district-level data 
only. These data were collected from a nationally representative sample of public school districts through computer-assisted telephone interviews or self-administered mail questionnaires. During recruitment, the superintendent or other district-level contact designated a respondent for each questionnaire or questionnaire module. All designated respondents had primary responsibility for or were the most knowledgeable about the particular component.

At the end of the data collection period (October 2006), 50\% of completed district-level questionnaires had been administered via telephone interviews and the remaining 50\% had been completed as self-administered paper questionnaires. Results did not differ significantly by mode of administration (13).

Response rates for the questionnaires and the number of districts completing questionnaires varied depending on the school health program component. For each component, the response rate was calculated by dividing the number of districts that completed at least one module in that component by the number of eligible districts for that component. For health education, the response rate was $64 \%$ ( $n=459$ districts); physical education and activity, 63\% $(\mathrm{n}=453)$; health services, $63 \%(\mathrm{n}=449)$; nutrition services, 64\% ( $n=455)$; healthy and safe school environment, 64\% $(n=461)$; and faculty and staff health promotion, $64 \%(\mathrm{n}=461)$. A more detailed description of SHPPS 2006 methods has been published previously (14). The CDC's Institutional Review Board determined that SHPPS 2006 was exempt from review.

\section{Procedure}


The authors matched each element in the wellness policy coding system with the relevant SHPPS 2006 questions. Elements that could not be matched to any SHPPS 2006 questions were excluded from analyses. For several elements, only one SHPPS question was relevant, so the match was evident. That is, if a district answered "yes" to a SHPPS question that was matched to the element, that district was considered to have "met" the element. For other items, several SHPPS questions were relevant, and in those cases, the authors decided which combination of questions would provide data to assess whether districts were meeting that element. For some elements, a district must have answered "yes" to all questions, for other elements, a "yes" answer to any one of several questions was sufficient for the district to have met the element (see Table 1).

\section{Data Analysis}

All districts that responded to the question or questions relevant to a given element were included in the analysis of that element. All analyses used SUDAAN statistical analysis software (version 9.0.0, 2004, Research Triangle Institute, Research Triangle Park, NC) to account for the complex sampling design used in SHPPS 2006. Data were weighted to be representative of all public school districts in the United States. All percentages reported therefore represent the percentage of all districts in the United States meeting each element. As a measure of variability, $95 \%$ confidence intervals were calculated for each reported percentage.

\section{RESULTS}


In the area of nutrition education, $14.6 \%$ of districts met all four elements that could be matched to SHPPS questions. Each of these elements was met by more than one-half of districts, with the largest percentage of districts meeting the element related to coordinating nutrition education with the larger school community (Table 1).

Eight elements related to standards for USDA child nutrition programs and meals were matched to SHPPS questions, but no district met more than six elements. While nearly all districts ensured training or professional development for food service staff and more than three-fourths addressed access to and/or promotion of the USDA School Breakfast Program, far fewer districts met the other elements in this subscale (Table 1). Eleven elements related to standards for other competitive foods and beverages could be matched to SHPPS questions. Nearly one-fourth of districts did not meet any of these elements, and no district met more than nine. Relatively few districts regulated vending machines, school stores, food served at class parties and other school celebrations, food sold at evening and community events on school grounds, and food sold for fundraising (Table 1).

In the area of physical education, 13 elements were matched to SHPPS questions, but only $0.1 \%$ of districts met all 13 elements. Five elements were met by more than $80 \%$ of districts (Table 1).

Five elements related to physical activity were matched to SHPPS questions, but only $0.1 \%$ of districts met all five of these elements, and $31.9 \%$ did not meet any. Nearly one-half of districts addressed recess frequency or amount in elementary schools by requiring these schools to provide students with at least 20 minutes of regularly scheduled recess per day (Table 1). 
In the area of communication and promotion, four elements could be matched to SHPPS questions, but less than $0.1 \%$ of districts met all four, and $16.6 \%$ did not meet any. Few districts specified restricting marketing of unhealthful choices.

Only one element related to evaluation could be matched to SHPPS questions.

Less than one-half of districts evaluated district or school food service staff compliance with government regulations and recommendations and evaluated physical education policies during the two years before the study (Table 1).

\section{Summary Analysis}

For each of the goal area subscales, except Evaluation, in which only one element was measured, the number of elements each district met was calculated and then averaged across all sampled districts. These averages, the total number of elements measured, and the mean expressed as a percentage of the total possible number of elements are shown in Table 2. The average percentage of elements met ranged from $20 \%$ for physical activity to $55 \%$ for nutrition education.

\section{DISCUSSION}

This study is the first to use existing data to provide a baseline measure of the extent to which school districts were implementing elements of wellness policies contained in a standardized coding scheme before the Child Nutrition and WIC Reauthorization Act of 2004 was implemented. In line with the study hypothesis, in 2006, no district met all elements included in the coding scheme. The coding scheme, however, includes elements that go above and beyond what is required by the legislation. Many 
districts in 2006 might have met the minimum requirements, as has been shown in other studies $(4,6)$.

This study also found that the percentage of districts meeting each element varied widely. Such a finding is consistent with those of previously published wellness policy studies that used different methods $(2-4,6-9,11)$. Variability among districts was present even within each goal area subscale. For example, although more than $90 \%$ of districts ensured training or professional development for school food service staff, less than $2 \%$ required nutrition qualifications for such staff.

Previous studies assessing the quality of local school wellness policies have found that the majority of district policies met the minimum requirements of the law, but by using the Schwartz et al. (11) coding scheme, this study determined the extent to which school districts in 2006 were implementing policies that went beyond those requirements. Chriqui and colleagues (6) used a modified version of this scheme in their nationwide evaluation of wellness policies. Comparing results from that study with those of the present study reveals some interesting similarities and differences. For example, the present study found that $13.7 \%$ of districts addressed nutrition standards for school meals beyond USDA minimum standards; Chriqui and colleagues found that a similar percentage of students attended school in districts with such a policy provision. On the other hand, while the present study found that more than one-half of districts made nutrition information for school meals available, in Chriqui's study, less than $20 \%$ of students were in districts with such a policy provision as of the beginning of the 2006-07 school year (and only $28 \%$ as of the beginning of the 2007-08 school year) (6). This difference most likely reflects an important distinction between practice and policy. That 
is, districts can and do make nutrition information available even when no policy is in place requiring them to do so. In developing and revising policies, districts should be encouraged to include information about all of their wellness-related practices. This will enable a better match between policy and practice.

The mismatch between practice and policy can also occur in the opposite direction. A policy might say more in writing than what is actually implemented, because some elements of the policy might be easier to implement than others. For example, a recent study demonstrated that beverage standards were more likely to be implemented than were nutrient-based food standards (15). As schools work toward implementation and monitoring of local wellness policies, the difference between policy and practice warrants consideration. Although having strong policies is important, districts and schools vary regarding implementation of policies and may need additional support to implement and monitor them. Longley and Sneed (4) found that significant changes have been made to school nutrition environments as a result of the implementation of wellness policies. Strong policies promote environments that enhance nutrition and help students develop lifelong healthy behaviors. School nutritionists can assist in improving wellness policies by educating school board and local government decision makers, assessing the school nutrition environment to recommend improvements to current policies, and serving on school wellness committees or school health advisory councils. Additional research is still needed, however, to determine the best way to assist districts and schools in the implementation and monitoring of these policies.

Recent surveys of school board members, school district nutrition directors and superintendents, state school board association leaders, and members of national 
education and health organizations provide some insight into why districts lack strong school wellness policies (16-19). Barriers include inadequate funding; competing priorities; insufficient time in the school day; lack of support from students, parents, and community members; and lack of adequate tools and training to support those responsible for policy development, implementation, and evaluation (16-19). Some of these barriers are more surmountable than others. For example, tools such as Fit, Healthy, and Ready to Learn can assist in policy development (20). In addition, states have made widespread efforts to help school districts develop, implement, and monitor their wellness policies. By the end of 2007, at least 48 states had developed guidance materials or adopted new laws, regulations, or policies addressing the federal legislation mandating school wellness policies (17). For example, at least 19 states disseminated their own model wellness policies, at least seven states distributed needs assessment and policy development instruments, and at least three states produced summaries of existing state laws and policies to support development of wellness policies (21).

Even if all districts have ideal school wellness policies in place, it is unlikely that this alone will reverse the problem of obesity among our nation's children. While developing strong policies is an important first step, if such policies are not implemented at the school level, they will not achieve the goals they are designed to reach. Although most districts have wellness policies, great variation in implementation and evaluation exists across districts (6). It is critical that districts support schools in the implementation of wellness policies by providing training and technical assistance for individuals at the school level who are responsible for or involved with implementing local policies. This may include food service directors, principals, physical educators, athletic directors, 
teachers, nurses, school health or wellness council members, parents, students, and community members. It also is important to monitor the implementation of these policies at the school level. National surveys such as SHPPS provide comprehensive data on school-level practices related to nutrition and physical activity.

\section{Limitations}

This study has several limitations. First, SHPPS was not designed to measure the extent to which districts have specific elements of local wellness policies in place. As a result, many of the elements could not be matched to SHPPS questions and had to be omitted from the analysis. SHPPS questions also did not always provide an exact measure of each policy element, although the measures were reasonable proxies. Second, although the coding scheme used in this study was designed to score policies on both comprehensiveness and strength, this analysis could only measure comprehensiveness, because each element could only be coded as being met or not being met based on how the district answered the relevant question or questions. Third, SHPPS district-level data do not provide actual policies, but instead provide interpretations of those policies by each district's most knowledgeable respondent. These interpretations might be different from what is officially "on the books." Finally, SHPPS data do not differentiate policies based on grade level. Thus, the reported policies may not be applied consistently across all grade levels within a given district. Based on the results of the nationwide evaluation of wellness policies conducted by Chriqui et al. (6), it is quite likely that policies governing certain topics (i.e., competitive foods) will vary greatly based on grade level. Therefore, the findings in the current study should not be interpreted to mean that the 
reported policy provisions are being consistently applied to all grades throughout each district.

\section{CONCLUSIONS}

The results of this study indicate areas of strength and weakness in the implementation of local school wellness-related policies before the policy requirement took effect. In 2006, district policies were strong in coordinating nutrition education with the larger school community and ensuring training or professional development for food service staff. Room for improvement existed in multiple areas, however, such as specifying use of low-fat foods and low-fat methods for preparing foods, and providing regular physical activity opportunities throughout the school day, not including recess. Tools and resources available to assist districts in strengthening their policies in these areas include those from state school board associations, Action for Healthy Kids (22), Alliance for a Healthier Generation (23), National Alliance for Nutrition and Activity (24), and Project LEAN (25).

It is critical to continue to monitor local wellness policies to determine the extent to which such policies have improved since 2006. While collecting and analyzing written policies is one way to accomplish this, school nutritionists and others working in this area should continue to seek out other methods for monitoring policies, such as the novel approach used in this study. Applying a coding scheme for district policies to an existing dataset proved to be a useful method for establishing a baseline measure of wellness policies that go beyond minimum federal requirements. The true utility of this method, however, will be seen when SHPPS is repeated in 2012. CDC has revised the SHPPS 
2012 questionnaires to ensure that more elements in the coding system can be matched to SHPPS questions. The current analysis can then be repeated to determine the extent to which district wellness policies have improved relative to the baseline information presented in the current study. Such analyses provide one method for systematically monitoring district progress in improving local wellness policies. Future research should seek out and apply additional methods for monitoring these policies and their implementation. 


\section{References}

1. Child Nutrition and WIC Reauthorization Act of 2004. Public Law No. 108-265 Stat $729, \S 204$.

2. Metos J, Nanney MS. The strength of school wellness policies: one state's experience. J Sch Health. 2007;77:367-372.

3. Moag-Stahlberg A, Howley N, Luscri L. A national snapshot of local school wellness policies. J Sch Health. 2008;78:562-568.

4. Longley $\mathrm{CH}$, Sneed J. Effects of federal legislation on wellness policy formation in school districts in the United States. J Am Diet Assoc. 2009;109:95-101.

5. Probart C, McDonnell E, Weirich E, Schilling L, Fekete V. Statewide assessment of local wellness policies in Pennsylvania public school districts. $J$ Am Diet Assoc. 2008;108:1497-1502.

6. Chriqui JF, Schneider L, Chaloupka FJ, Gourdet C, Bruursema A, Ide K, Pugach O. School District Wellness Policies: Evaluating Progress and Potential for Improving Children's Health Three Years After the Federal Mandate. School Years 2006-07, 2007-08, and 2008-09. Vol. 2. Chicago, IL: Bridging the Gap Program, Health Policy Center, Institute for Health Research and Policy, University of Illinois at Chicago, 2010. http://www.bridgingthegapresearch.org/research/district_wellness_policies/. Accessed October 25, 2010.

7. Belansky ES, Cutforth N, Delong E, Ross C, Scarbro S, Gilbert L, Beatty B, Marshall J. Early impact of the federally mandated local wellness policy on 
physical activity in rural, low-income elementary schools in Colorado. J Public Health Policy. 2009;30:S141-S160.

8. School Nutrition Association. A foundation for the future: analysis of local wellness policies from the largest 100 school districts. School Nutrition Association, 2006. http://www.schoolnutrition.org/uploadedFiles/School_Nutrition/102_ResourceCe nter/Running YourProgram/LocalSchoolWellnessPolicies/SNA100DistrictLWPRe port.pdf. Accessed June 1, 2010.

9. School Nutrition Association. A foundation for the future II: analysis of local wellness policies from 140 school districts in 49 states. School Nutrition Association, 2006. http://www.schoolnutrition.org/Content.aspx?id=8504. Accessed June 1, 2010.

10. Action for Healthy Kids. Wellness Policy Fundamentals. http://www.actionforhealthykids.org/school-programs/our-programs/wellnesspolicy-tool/wellness-policy-fundamentals.pdf. Accessed June 1, 2010.

11. Schwartz MB, Lund AE, Grow M, McDonnell E, Probart C, Samuelson A, Lytle L. A comprehensive coding system to measure the quality of school wellness policies. J Am Diet Assoc. 2009;109:1256-1262.

12. Rudd Center for Food Policy \& Obesity, Yale University. Wellness School Assessment Tool. http://wellsat.org. Accessed June 2, 2010.

13. Denniston M, Brener ND. A comparison of mail and telephone administration of district-level questionnaires for the School Health Policies and Programs Study 
(SHPPS) 2006: effects on estimates and data quality. J Sch Health. 2010;80:304311.

14. Kyle TM, Brener ND, Kann L, Ross JG, Roberts AM, Iachan R, Robb WH, McManus T. Methods: School Health Policies and Programs Study 2006. J Sch Health. 2007;77:398-407.

15. Samuels SE, Bullock SL, Woodward-Lopez G, Clark SE, Kao J, Craypo L, Barry J, Crawford PB. To what extent have high schools in California been able to implement state-mandated nutrition standards? J Adolesc Health. 2009;45(3 Suppl):S38-S44.

16. California School Boards Association, California Project LEAN. School Wellness Policy Development, Implementation and Evaluation. Sacramento, CA: California School Boards Association, California Project LEAN; 2008.

17. Action for Healthy Kids. Progress or promises? What's working for and against healthy schools. Skokie, IL: Action for Healthy Kids, 2008. http://www.actionforhealthykids.org/resources/research-and-reports/progress-orpromises-what-s-working-for-and-against-healthy-schools.html. Accessed June 1, 2010.

18. School Nutrition Association. From cupcakes to carrots: local wellness policies one year later. School Nutrition Association, 2007. http://www.schoolnutrition.org/uploadedFiles_old/ASFSA/newsroom/pressreleas es/From_Cupcakes_to_Carrots.pdf. Accessed June 1, 2010.

19. Probart C, McDonnell ET, Jomaa L, Fekete V. Lessons from Pennsylvania's mixed response to federal school wellness law. Health Aff. 2010;29(3):447-453. 
20. National Association of State Boards of Education. Fit, Healthy, and Ready to Learn: A School Health Policy Guide. Washington, DC: National Association of State Boards of Education, 2000.

21. Pekruhn CE, Bogden JF. Issue Brief: State Strategies to Support Local Wellness Policies. Washington, DC: National Association of State Boards of Education, 2007.

22. Action for Healthy Kids. Resources to create change. http://www.actionforhealthykids.org/resources/

23. Alliance for a Healthier Generation. At school. http://www.healthiergeneration.org/schools

24. National Alliance for Nutrition and Activity. Resources for Local School Wellness Policies on Nutrition and Physical Activity. http//www.schoolwellnesspolicies.org/WellnessResources.html 25. Project LEAN. Tools and resources. http://www.californiaprojectlean.org/doc.asp?id=20 
Table 1. Percentage of school districts $(\mathrm{n}=538)$ meeting elements of local wellness policies from standardized coding scheme, according to School Health

Policies and Programs Study data-United States, 2006

\begin{tabular}{|c|c|c|c|}
\hline Element & $\begin{array}{c}\text { District-level School Health Policies and Programs Study } \\
\text { variables used to measure element }\end{array}$ & $\begin{array}{c}\% \text { of } \\
\text { districts }\end{array}$ & 95\% CI \\
\hline \multicolumn{4}{|c|}{ Nutrition education (4 of 9 elements matched) } \\
\hline NE2 Nutrition curriculum provided for each grade level. & $\begin{array}{l}\text { Adopted a policy stating that elementary, middle, and high } \\
\text { schools will teach about nutrition and dietary behavior }\end{array}$ & 56.6 & $49.1,63.8$ \\
\hline $\begin{array}{l}\text { NE3 Coordinates nutrition education with the larger school } \\
\text { community. }\end{array}$ & $\begin{array}{l}\text { District-level health education staff worked with district-level } \\
\text { nutrition or food service staff* }\end{array}$ & 91.9 & $88.1,94.5$ \\
\hline NE5 District provides nutrition education training for teachers. & $\begin{array}{l}\text { Provided staff development to those who teach health education } \\
\text { on nutrition and dietary behavior** }\end{array}$ & 65.3 & $58.9,71.1$ \\
\hline $\begin{array}{l}\text { NE6 Nutrition education is integrated into other subjects beyond } \\
\text { health education. }\end{array}$ & $\begin{array}{l}\text { Provided ideas on how to involve school food service staff in } \\
\text { classrooms or how to use the cafeteria as a place for learning* }\end{array}$ & 60.4 & $54.7,65.8$ \\
\hline \multicolumn{4}{|c|}{ Standards for USDA child nutrition programs and meals (8 of 13 elements matched) } \\
\hline $\begin{array}{l}\text { US11 Addresses access to and/or promotion of the School } \\
\text { Breakfast Program (USDA). }\end{array}$ & Adopted a policy that schools will offer breakfast to students & 82.8 & $77.9,86.9$ \\
\hline $\begin{array}{l}\text { US13 Addresses nutrition standards for school meals beyond } \\
\text { USDA minimum standards. }\end{array}$ & $\begin{array}{l}\text { Requires that schools offer students fruits, non-fried vegetables, } \\
\text { dairy products, and whole grains for breakfast/lunch }\end{array}$ & 13.7 & $10.5,17.7$ \\
\hline
\end{tabular}




\begin{tabular}{|c|c|c|c|}
\hline $\begin{array}{l}\text { US14 Specifies use of low-fat versions of foods and/or low-fat } \\
\text { methods for preparing foods. }\end{array}$ & $\begin{array}{l}\text { In preparing food for the district,*** almost always or always } \\
\text { used low-fat foods and low-fat methods for preparing foods }\end{array}$ & 1.4 & $0.5,3.7$ \\
\hline $\begin{array}{l}\text { US15 Specifies strategies to increase participation in school meal } \\
\text { programs. }\end{array}$ & $\begin{array}{l}\text { Adopted a policy that schools will encourage breakfast } \\
\text { consumption by allowing students to eat in alternate locations }\end{array}$ & 20.3 & $16.4,25.0$ \\
\hline US17 Ensures adequate time to eat. & $\begin{array}{l}\text { Requires a minimum amount of time students will be given to eat } \\
\text { breakfast and lunch once they are seated }\end{array}$ & 18.7 & $14.5,23.8$ \\
\hline $\begin{array}{l}\text { US19 Requires nutrition qualifications for school food service } \\
\text { staff. }\end{array}$ & $\begin{array}{l}\text { Requires minimum education and certification for newly hired } \\
\text { school food service managers/district food service directors }\end{array}$ & 1.8 & $0.8,3.9$ \\
\hline $\begin{array}{l}\text { US20 Ensures training or professional development for food } \\
\text { service staff. }\end{array}$ & $\begin{array}{l}\text { Provided funding for or offered staff development to food service } \\
\text { staff on any of } 19 \text { topics** }\end{array}$ & 95.8 & $92.9,97.5$ \\
\hline $\begin{array}{l}\text { US22 Nutrition information for school meals (e.g., calories, } \\
\text { saturated fat, sugar) is available. }\end{array}$ & $\begin{array}{l}\text { Provided students or families with information on the nutrition } \\
\text { and caloric content of foods available to them* }\end{array}$ & 51.6 & $46.2,57.0$ \\
\hline \multicolumn{4}{|c|}{ Standards for competitive and other foods and beverages (11 of 28 elements matched) } \\
\hline NS24 Regulates vending machines. & $\begin{array}{l}\text { Requires that schools be prohibited from offering junk foods in } \\
\text { vending machines and that schools prohibit some student access }\end{array}$ & 12.6 & $9.3,16.9$ \\
\hline NS25 Regulates school stores. & $\begin{array}{l}\text { Requires that schools be prohibited from offering junk foods in } \\
\text { school stores, canteens, or snack bars }\end{array}$ & 18.9 & $14.6,24.1$ \\
\hline NS26 Regulates food service a la carte. & Requires that schools be prohibited from offering junk foods a la & 27.7 & $22.2,34.0$ \\
\hline
\end{tabular}




\begin{tabular}{|c|c|c|c|}
\hline & $\begin{array}{l}\text { carte during breakfast or lunch periods and have contracts that } \\
\text { specifically address nutritional standards for a la carte foods }\end{array}$ & & \\
\hline $\begin{array}{l}\text { NS27 Regulates food served at class parties and other school } \\
\text { celebrations. }\end{array}$ & $\begin{array}{l}\text { Requires that schools be prohibited from offering junk foods at } \\
\text { student parties }\end{array}$ & 11.5 & $8.2,15.9$ \\
\hline $\begin{array}{l}\text { NS31 Regulates food sold at evening and community events on } \\
\text { school grounds. }\end{array}$ & $\begin{array}{l}\text { Requires that schools be prohibited from offering junk foods at } \\
\text { concession stands }\end{array}$ & 5.4 & $3.4,8.6$ \\
\hline NS32 Regulates food sold for fundraising. & $\begin{array}{l}\text { Requires that schools prohibit junk foods from being sold for } \\
\text { fundraising purposes }\end{array}$ & 13.8 & $10.4,18.2$ \\
\hline NS37 Addresses limiting serving size of foods. & $\begin{array}{l}\text { Requires that schools limit the package or serving size of food or } \\
\text { beverage items }\end{array}$ & 27.6 & $21.9,34.1$ \\
\hline $\begin{array}{l}\text { NS38 Addresses increasing "whole foods": whole grains, } \\
\text { unprocessed foods, or fresh produce. }\end{array}$ & $\begin{array}{l}\text { Requires that schools make fruits or vegetables available to } \\
\text { students whenever other food is offered or sold }\end{array}$ & 6.6 & $4.4,9.8$ \\
\hline $\begin{array}{l}\text { NS39 Addresses limiting the use of ingredients with questionable } \\
\text { health effects in food or beverages }\end{array}$ & $\begin{array}{l}\text { Requires that schools restrict the times during the day that junk } \\
\text { foods can be sold in any venue }\end{array}$ & 57.4 & $51.4,63.1$ \\
\hline $\begin{array}{l}\text { NS40 Addresses food not being used as a reward and/or withheld } \\
\text { as a punishment. }\end{array}$ & $\begin{array}{l}\text { Adopted a policy prohibiting schools from using food or food } \\
\text { coupons as a reward }\end{array}$ & 26.1 & $21.3,31.5$ \\
\hline NS42 Addresses limiting sugar content of beverages. & $\begin{array}{l}\text { Requires that schools restrict the times during the day that soda } \\
\text { pop, sports drinks, or fruit drinks can be sold in any venue }\end{array}$ & 63.0 & $57.2,68.5$ \\
\hline
\end{tabular}




\begin{tabular}{|c|c|c|c|}
\hline \multicolumn{4}{|c|}{ Physical education (13 of 17 elements matched) } \\
\hline $\begin{array}{l}\text { PE52 Addresses physical education curriculum for each grade } \\
\text { level. }\end{array}$ & $\begin{array}{l}\text { Adopted a policy stating that elementary, middle, and high } \\
\text { schools will teach physical education }\end{array}$ & 72.8 & $65.7,78.9$ \\
\hline $\begin{array}{l}\text { PE53 Addresses time per week of physical education for } \\
\text { elementary school students. }\end{array}$ & $\begin{array}{l}\text { Has specified time requirements for physical education at the } \\
\text { elementary school level }\end{array}$ & 81.6 & $76.1,86.0$ \\
\hline $\begin{array}{l}\text { PE54 Addresses time per week of physical education for middle } \\
\text { school students. }\end{array}$ & $\begin{array}{l}\text { Has specified time requirements for physical education at the } \\
\text { middle school level }\end{array}$ & 81.7 & $75.5,86.5$ \\
\hline $\begin{array}{l}\text { PE55 Addresses time per week of physical education for high } \\
\text { school students. }\end{array}$ & $\begin{array}{l}\text { Has specified time requirements for physical education at the } \\
\text { high school level }\end{array}$ & 91.4 & $86.4,94.7$ \\
\hline $\begin{array}{l}\text { PE57 Specifies competency assessment (i.e., knowledge, skills, } \\
\text { or practice). }\end{array}$ & $\begin{array}{l}\text { Requires that elementary, middle, and high schools give written } \\
\text { tests of students' knowledge and skill performance tests }\end{array}$ & 1.2 & $0.5,2.7$ \\
\hline PE58 Addresses physical education quality. & $\begin{array}{l}\text { Adopted a policy stating that schools will follow any national, } \\
\text { state, or district physical education standards or guidelines }\end{array}$ & 84.0 & $78.8,88.0$ \\
\hline PE59 Physical education program promotes inclusive play. & $\begin{array}{l}\text { Follows physical education standards or guidelines that are based } \\
\text { on the National Standards for Physical Education }\end{array}$ & 55.4 & $48.9,61.7$ \\
\hline PE62 Addresses teacher-student ratio for physical education. & Adopted a policy specifying a maximum student-to-teacher ratio & 12.8 & $9.5,17.0$ \\
\hline $\begin{array}{l}\text { PE63 Addresses safe and adequate equipment and facilities for } \\
\text { physical education. }\end{array}$ & $\begin{array}{l}\text { Adopted a policy requiring that students wear appropriate } \\
\text { protective gear during physical education }\end{array}$ & 43.6 & $37.2,50.2$ \\
\hline
\end{tabular}




\begin{tabular}{|c|c|c|c|}
\hline PE65 Addresses qualifications for physical education instructors. & $\begin{array}{l}\text { Adopted a policy stating that newly hired staff who teach } \\
\text { physical education will be certified, licensed, or endorsed }\end{array}$ & 71.9 & $64.2,78.5$ \\
\hline $\begin{array}{l}\text { PE66 District provides physical education training for physical } \\
\text { education teachers. }\end{array}$ & $\begin{array}{l}\text { Provided funding for or offered staff development to those who } \\
\text { teach physical education on any of } 16 \text { topics** }\end{array}$ & 90.9 & $86.7,93.8$ \\
\hline $\begin{array}{l}\text { PE67 Addresses physical education waiver requirements (e.g., } \\
\text { substituting physical education requirement with other activities). }\end{array}$ & $\begin{array}{l}\text { Adopted a policy stating that students cannot be exempted from } \\
\text { physical education requirements for certain reasons }\end{array}$ & 40.6 & $33.3,48.3$ \\
\hline $\begin{array}{l}\text { PE68 Requires students to participate in an annual health } \\
\text { assessment (e.g., fitness or Body Mass Index [BMI]). }\end{array}$ & $\begin{array}{l}\text { Requires that schools test students' fitness levels or screen } \\
\text { students for height and weight or body mass index problems }\end{array}$ & 42.7 & $36.5,49.3$ \\
\hline \multicolumn{4}{|c|}{ Physical activity (5 of 10 elements matched) } \\
\hline PA71 Includes physical activity opportunities for school staff. & $\begin{array}{l}\text { Provided funding for or offered any physical activity programs } \\
\text { for faculty and staff* }\end{array}$ & 36.3 & $31.3,41.6$ \\
\hline $\begin{array}{l}\text { PA72 Regular physical activity opportunities are provided } \\
\text { throughout the school day (not including recess). }\end{array}$ & $\begin{array}{l}\text { Requires schools to provide regular physical activity breaks, } \\
\text { outside of physical education class and recess }\end{array}$ & 1.0 & $0.3,3.2$ \\
\hline PA75 Addresses safe, active routes to school. & Adopted a policy that supports walking/biking to and from school & 17.5 & $13.5,22.5$ \\
\hline $\begin{array}{l}\text { PA76 Addresses not using physical activity (extra or restricted) } \\
\text { as punishment. }\end{array}$ & $\begin{array}{l}\text { Prohibits or actively discourages schools from using physical } \\
\text { activity or exclusion from physical activity to punish students }\end{array}$ & 22.9 & $18.0,28.6$ \\
\hline $\begin{array}{l}\text { PA77 Addresses recess frequency or amount in elementary } \\
\text { school. }\end{array}$ & $\begin{array}{l}\text { Requires that elementary schools provide students regularly } \\
\text { scheduled recess for } 20 \text { or more minutes per day }\end{array}$ & 44.3 & $38.0,50.8$ \\
\hline
\end{tabular}




\begin{tabular}{|c|c|c|c|}
\hline \multicolumn{4}{|c|}{ Communication and promotion (4 of 12 elements matched) } \\
\hline $\begin{array}{l}\text { CP80 Includes staff wellness programs specifically addressing } \\
\text { the health of staff. }\end{array}$ & $\begin{array}{l}\text { Provided funding for or offered wellness activities for faculty and } \\
\text { staff* }\end{array}$ & 41.6 & $36.2,47.3$ \\
\hline $\begin{array}{l}\text { CP86 Specifies how district will engage parents or community to } \\
\text { meet district wellness goals. }\end{array}$ & $\begin{array}{l}\text { Provided families with information on the school food service, } \\
\text { physical education, or physical activity programs* }\end{array}$ & 58.6 & $51.9,65.0$ \\
\hline CP89 Specifies restricting marketing of unhealthful choices. & $\begin{array}{l}\text { Requires that schools prohibit advertisements and promotions for } \\
\text { soft drinks, candy, or fast food restaurants on school property }\end{array}$ & 5.1 & $3.0,8.4$ \\
\hline $\begin{array}{l}\text { CP90 Establishes a health advisory committee or school health } \\
\text { council that is ongoing beyond policy development. }\end{array}$ & $\begin{array}{l}\text { Has one or more than one school health council, committee, or } \\
\text { team that met at least one time* }\end{array}$ & 68.2 & $62.9,73.1$ \\
\hline \multicolumn{4}{|c|}{ Evaluation (1 of 6 elements matched) } \\
\hline $\begin{array}{l}\text { E94 Addresses the audience and frequency of a report on } \\
\text { compliance and/or evaluation. }\end{array}$ & $\begin{array}{l}\text { Physical education policies and food service staff compliance } \\
\text { with government regulations have been evaluated }{ }^{* *}\end{array}$ & 45.6 & $39.1,52.3$ \\
\hline
\end{tabular}

*During the 12 months before the study.

**During the 2 years before the study.

***During the 30 days before the study. 
Table 2. Average number of local wellness policy elements from standardized coding scheme met for each goal area ( $\mathrm{n}=538$ districts) — United States, 2006

\begin{tabular}{|l|c|c|}
\hline \multicolumn{1}{|c|}{ Goal area } & $\begin{array}{c}\text { Total elements } \\
\text { matched to SHPPS }\end{array}$ & $\begin{array}{c}\text { Average number of } \\
\text { elements met }\end{array}$ \\
\hline (\% of total)
\end{tabular}

